\title{
Kerukunan Hidup Berdampingan Secara Damai Antara Umat Muslim Dan Kristen Di Ngerukopa
}

\author{
Lutfin Haryanto ${ }^{1}$, Abas Oya ${ }^{2}$, Rostati $^{3}$, Jessy Parmawati Atmaja ${ }^{4}$ \\ ${ }^{1234}$ STKIP Harapan Bima \\ Email:lutfinharyanto1990@gmail.com,abasoya01@gmail.com,tathysanggini3526@gmail.com,

\section{jessyparmawatiatmaja@habi.ac.id}

\begin{abstract}
English). Religious tolerance in Indonesia is already popular with the term life of harmoniousness. Adherents of different religions have been spreading in the provinces of Indonesia. Village people in Nggerukopa embrace a different religion between Islam, Christianity and Catholicism. The researchers discussed "how peaceful harmony exists between Muslims and Christians in Nggerupa?". The study used qualitative methods with phenomenology approach. The steps of the data collection are observation, interview and documentation with a purposive sampling technique. The researchers found some of the patterns did by people of different religions in Nggerukopa of filling peaceful coexistence between Muslims and Christians in destroying social interaction between them, and patterns of religious social relationships, and society social relationships. It embodies attitudes of tolerance by being able to live each other's lives without having to care for the differences; there are differences in belief toward held religion so that tolerance and religious harmony could be created properly.
\end{abstract}

Keywords: Harmoniousness, Peaceful Life, Religious Differences.

Abstrak . Toleransi antar umat beragama di Indonesia sudah populer dengan istilah kerukunan hidup antar umat beragama. Penganut agama yang berbeda sudah meluas diberbagai propinsi di Indonesia. Masyarakat Dusun Nggerukopa menganut agama yang berbeda diantaranya Islam, Kristen dan Khatolik. Para peneliti mengkaji "Bagimana kerukunan hidup berdampingan secara damai antara umat kristen dan muslim di Nggerukopa?". Penelitian ini menggunakan metode kualitatif dengan pendekatan fenomenologi. Langkah dalam pengumpulan data yaitu observasi, wawancara dan dokumentasi dengan teknik purposive sampling. Para Peneliti menemukan beberapa pola yang dilakukan oleh umat berbeda agama di Nggerukopa dalam memenuhi hidup berdampingan secara damai antar umat Kristen Dan Muslim Di Ngerukopa diantaranya pola interaksi sosial masyarakat, dan pola hubungan sosial keagamaan, serta pola hubungan sosial kemasyarakatan. Hal tersebut mewujudkan sikap toleransi mereka dengan mampu menjalani kehidupannya masing-masing tanpa harus memperdulikan perbedaan yang ada termasuk adanya perbedaan keyakinan terhadap agama yang dianut sehingga sikap toleransi dan kerukunan beragama dapat tercipta dengan baik.

Kata Kunci: Kerukunan, Hidup Damai, Perbedaan Agama

\section{PENDAHULUAN}

Agama memainkan peranan yang penting dalam kehidupan sehari-hari orang Indonesia. Hal ini merupakan bagian dari identitas pribadi, identitas etnik dan juga identitas politik seseorang, serta identitas bangsa itu sendiri. Indonesia adalah negara yang beragam agama, dengan kekayaan agama dan kepercayaan, meskipun sebagian besar rakyatnya (sekitar 90 persen) mengaku beragama islam.

Penganut agama yang bereda sudah meluas diberbagai propinsi di Indonesia. Salah satunya di provinsi Nusa Tenggara Barat, kecamatan Donggo, kabupaten Bima, desa Palama, dusun Nggerukopa. Masyarakat Nggerukopa menganut agama yang berbeda diantaranya Islam, Kristen dan Khatolik. 
Tentunya hidup dengan perbedaan keyakinan di satu tempat tidaklah muda bagi umat tersebut. Tantangan dan masalah bukan lagi hal yang dapat dihindari dan ditutupi dalam kehidupan sehari-hari.

Perbedaan cenderung menghasilkan sebuah konflik. Baik itu perbedaan suku, ras, maupun agama. Dikarenakan disetiap kelompok memiliki kepercayaan dan keyakinan masingmasing, terutama dalam perbedaan agama sangat sensitif dan mudah menimbulkan sebuah konflik. Maka dari itu, toleransi menjadi peranan penting bagi mereka dalam di kehidupan sehari-hari.

Beberapa penelitian terdahulu
membahas tentang toleransi beragama. Musyarif ( 2018) dalam tulisannya yang berjudul "Toleransi Islam Dan Kristen Di Kabupaten Soppeng Tahun 1950-2007”, mengatakan sikap saling menghormati antara sesama sehingga sikap toleransi dapat terwujud antar umat beragama, dengan berlapang dada menghormati keyakinan mereka, sehingga membawa kepada kehidupan yang damai, harmonis dan sentosa, Untuk itu dianjurkan untuk bersikap lemah lembut pada sesama baik yang beragama Islam maupun yang beragama Nasrani atau lainnya. Imam Syaifudin (2017), dalam tulisannya "Interaksi Sosial Dalam Membangun Toleransi Antar Umat Beragama Di Dusun Dodol Desa Wonoagung Kecamatan Kasembon Kabupaten Malang", dari hasil penelitiannya menemukan bahwa terciptanya kerukunan, karena masingmasing dari setiap pemeluk agama saling terbuka dan menerima keberadaan dari agama lain. Lely Nisvilyah (2013), Toleransi Antarumat Beragama Dalam Memperkokoh Persatuan Dan Kesatuan Bangsa (Studi Kasus Umat Islam Dan Kristen Dusun Segaran Kecamatan Dlanggu Kabupaten Mojokerto), dalam hasil penelitiannya menunjukkan bahwa secara normative nilai-nilai dasar yang menjadi landasan terbentuknya toleransi antar umat beragama adalah nilai agama dan nilai budaya. Sedangkan, secara empirik terdiri atas nilai kemanusiaan, nasionalisme, historis, keteladanan tokoh masyarakat, dan nilai kesabaran. Penelitian lain juga membahas tentang toleransi beragama seperti, Eko Digdoyo (2018), Kajian Isu Toleransi
Beragama, Budaya, Dan Tanggung Jawab Sosial Media. Ahmad Zamakhsari

(2019), Kontestasi Umat Beragama (Studi Tentang Perdamaian dan Ketegangan Islam-Kristen di Kota Bekasi). Adeng Muchtar Ghazali (2016), Toleransi Beragama Dan Kerukunan Dalam Perspektif Islam. Yusuf Faisal Ali (2017), Upaya Tokoh Agama Dalam Mengembangkan Sikap Toleransi Antarumat Beragama. Salma (2016), "Konsep Toleransi (Al-Samahah) Antar Umat Beragama Perspektif Islam". Oluwatosin Adeoti A. (2014), "Religious Tolerance and Peaceful CoExistence: The Case of Female Religious Cults Relationship in Ijebuland, Ogun State Nigeria". Abdulazeez Balogun (2013), "Peaceful CoExistence in a Multi-Religious.

Dari penelitian-penelitian diatas mengarah pada bentuk toleransi. Di penelitian ini, kami mengkaji "Bagimana kerukunan hidup berdampingan secara damai antara umat kristen dan muslim di Nggerukopa?"

\section{METODE}

Penelitian menggunakan metode kualitatif dengan pendekatan fenomenologi, karena dalam proses penelitian, peneliti mengharapkan mampu memperoleh data dari orang-orang atau pelaku yang diamati baik secara tertulis maupun lisan. Penelitian ini dilakukan di Dusun Nggerukopa, Desa Palama, Kecamatan Donggo, Kabupaten Bima, Provinsi Nusa Tenggara Barat.

Sumber data dalam penelitian ini diperoleh oleh dari sumbernya secara langsung, diamati dan dicatat secara langsung, seperti, wawancara, observasi, dan dokumentasi dengan pihak yang terkait, yaitu tokoh agama, tokoh masyarakat dan masyarakat lainya. Pemilihan informan dalam penelitian ini dilaksanakan dengan cara atau teknik purposive sampling. Adapun analisis data yang digunakan dalam penelitian ini adalah teknik analisis kualitatif dari data yang diperoleh selama penelitian

\section{HASIL DAN PEMBAHASAN \\ Makna kerukunan antarumat beragama}

Toleransi antar umat beragama di Indonesia sudah populer dengan istilah kerukunan hidup antar umat beragama. Istilah 
tersebut menjadi istilah resmi yang di gunakan oleh pemerintah. Kerukunan hidup beragama adalah salah satu tujuan pembangunan dalam bidang keagamaan di Indonesia. Gagasan ini muncul didasari oleh seiring meruncingnya hubungan antar umat beragama.

Kerukunan dapat dimaknai sebagai kondisi hidup maupun kehidupan yang mencerminkan suasana damai, tertib, tenteram, sejahtera, saling menghormati, saling menghargai, tenggang rasa, gotong royong sesuai dengan ajaran agama dan kepribadian bangsa Indonesia yang terkandung dalam Pancasila.

Demi memelihara kerukunan beragama, sikap toleransi harus dikembangkan untuk hidup berdampingan secara damai dan menghindari konflik. Konflik antar umat beragama biasanya disebabkan oleh sikap merasa paling benar dengan cara eliminasi kebenaran dari orang lain.

\section{Interaksi Masyarakat Nggerukopa Dalam Merawat Toleransi Bagi Kerukunan Beragama}

Masing-masing agama perlu mengisi pemahaman dan kegiatannya dengan hal-hal yang mendorong hubungan saling bekerjasama untuk semua orang. Seperti di Dusun Nggerukopa Kecamatan Donggo Kabupaten Bima, meskipun terdapat tiga agama yaitu Islam, Kristen dan khatolik masyarakatnya hidup berdampingan secara rukun, damai dan saling menghargai satu sama lain. Secara normatif nilai-nilai dasar yang menjadi landasan terbentuknya sikap toleransi antar umat beragama yaitu nilai agama, nilai budaya, nilai nasionalis, nilai historis, nilai keteladanan dan nilai kesabaran.

Keragaman bahasa dan budaya seperti pelangi dan taman kehidupan yang menjadi sangat menarik. Namun, sering terdengar orang cenderung merasa gelisah dan sulit menerima kenyataan akan keragaman agama. perbedaan bukanlah dijadikan perdebatan, yang terpenting adalah bagaimana perbedaan tersebut dapat dipadukan sehingga menghasilkan sebuah keharmonisan dalam kehidupan beragama menuju persatuan berbangsa dan bernegara.

Warga Dusun Nggerukopa hampir ratarata adalah pemeluk agama Islam dan Kristen, keduanya hampir seimbang dan lainya adalah agama Khattolik. Walaupun demikian, hal ini tidak menjadikan wilayah Dusun Nggerukopa harus mutlak menerapkan ajaran Islam ataupun Kristen kepada seluruh masyarakatnya. Setiap pemeluk agama saling terbuka dan menerima keberadaan dari agama lain. Adanya keanekaragaman beragama yang ada di Nggerukopa, tidak membuat hubungan interaksi antara warga Nggerukopa menjadi renggang dan kaku, justru hal ini membuat keindahan tersendiri yang bisa dilihat didalam pola interaksi bermasyarakat warga Nggerukopa. Masyarakat Dusun Nggerukopa tidak memandang adanya kelompok mayoritas ataupun minoritas ketika melakukan kegiatan yang bersifat sosial. Mereka selalu menanamkan rasa persaudaraan yang kuat dan menjunjung tinggi sikap gotong-royong.

\section{Interaksi Sosial Masyarakat Nggerukopa}

Kondisi kehidupan sehari-hari masyarakat Dusun Nggerukopa terlihat jelas pada semua suasana kehidupan sosial sehariharinya. Mereka hidup damai dan rukun saling berdampingan satu dengan yang lainnya walaupun mereka berbeda agama. Pola interaksi sosial dalam membangun kerukunan umat beragama, secara umum masyarakat Dusun Nggerukopa mempunyai pola interaksi yang sangat dinamik. Hal tersebut tergambarkan dari pola hubungan sosial keagamaan, pola hubungan sosial kemasyarakatan, dimana halhal tersebut menjelaskan bagaimana pola kerukunan umat beragama yang terjadi di Dusun Nggerukopa.

\section{Hubungan Sosial Keagamaan}

Umat beragama yang ada di Dusun Nggerukopa menjalankan ajaran agama yang telah digariskan oleh agamanya masing-masing, baik ajaran-ajaran ritual perorangan, kelompok, maupun dalam kehidupan sehari-hari. Pola sosial keagamaan yang secara riil membentuk interaksi sosial yang harmonis serta komunikasi sosial yang selalu terjadi antara pemeluk agama yang berbeda.

Masyarakat Nggerukopa berkeyakinan bahwa perbedaan faham keagamaan merupakan urusan individu dengan Tuhan. Keyakinan yang selalu mereka pegang dan tentang keimanan tidak bisa dilihat oleh orang lain. Kebebasan dalam hal memeluk agama sangat dijunjung 
tinggi oleh mereka, serta perbedaan agama tidak menjadi tembok pemisah yang suram bagi mereka dalam berinteraksi antar pemeluk agama yang berbeda. Contoh nyata ketika umat Islam merayakan hari raya Idul Fitri, maka umatKristen dan Khatolik pun juga ikut merayakannya, pada hari kedua Idul Fitri umat nonmuslim datang kerumah tetangga yang beragama Islam untuk melakukan halal bihalal. Begitupun pada hari raya natal ataupun nyepi, masyarakat Dusun Nggerukopa yang beragama Islam juga ikut serta dalam perayaan tersebut. Sehingga hari raya di Dusun Nggerukopa dalam satu tahun terdapat tiga hari raya yang di rayakan masyarakat tersebut.

Pola hubungan sosial keagamaan yang terjadi di dusun Nggerukopa juga dapat dilihat dari berbagai fenomena yang berkembang di masyarakat seperti halnya upacara kematian dan upacara-upacara keagamaan yang bersifat pribadi. Dalam hal upacara kematian, tradisi masyarakat Nggerukopa selalu memberikan bantuan ketika mereka sedang berta'jiah atau dalam bahasa jawa "ngelawat". Bantuan tersebut bisa berupa uang, beras dan kebutuhankebutuhan yang lainnya. Prilaku ini menunjukkan bahwa kebersamaan masyarakat dalam hal perbedaan agama tidak menjadi faktor penghambat, akan tetapi menjadi faktor perekat sosial yang kuat antar umat beragama demi tercapainya kerukunan.

\section{Hubungan Sosial Kemasyarakatan}

Masyarakat Nggerukopa adalah salah satu tipe masyarakat yang berbentuk paguyuban, dimana bentuk kehidupan bersama yang anggotaanggotanya dukunci oleh hubungan batin yang murni dan bersifat alamiah serta kekal. Dalam masyarakat dusun Dodol bentuk paguyuban biasanya dilihat dari sistem kekerabatan, keluarga dan pola pemukiman yang berdelatan.

Pola sosial kemasyarakatan yang berkembang di Nggerukopa telah menunjukan pada kehidupan sosial yang integrasi atau kerukunan. Hal tersebut telah dibuktikan selama masyarakat setempat tinggal ditempat itu belum pernah terjadi konflik yang dilatar belakangi oleh agama, bahkan mereka hidup berdampingan secara rukun dan damai, saling menghormati satu sama lain walaupun keyakinan mereka berbeda-beda. Kehidupan yang kian terpelihara tercipta karena adanya keterkaitan antara norma yang menjadi panduan masyarakat dengan nilai-nilai agama maupun nilai adat bahkan kebudayaan yang kemudian menjelma dalam sikap dan prilaku di kehidupan sehari-hari.

Upacara tradisional adalah sebagai bentuk kegiatan dalam mencapai potensi kerukunan yang ada di masyarakat. Hal tersebut diperlihatkan adanya potensi lokal atau pengetahuan asli dari masyarakat untuk tetap menjaga kerukunan hidup. Kebiasaan dalam hal kehidupan perorangan maupun kelompok yang mendekatkan tali persaudaraan yang kuat telah menjadi tradisi masyarakat Donggo, seperti tradisi selametan, tradisi ini memiliki nilai spiritual dan sosial yang sangat tinggi. Selamatan dalam tradisi orang Donggo perlu dilihat dari aspek waktu biasanya dilakukan pada hari yang baik secara agama semisal malam Jum'at. Partisipasi dari orang-orang terdekat seperti tetangga dan saudara satu keturunan menjadi lebih terlihat, dalam acara selamatan tamu yang datangpun tidak membedakan dari segi etnis dan agama apa. Bentuk acara yang paling lumrah yaitu ketika seorang anaknya dikhitan, orang tua sang anak akan mengadakan acara selamatan untuk meminta do'a restu kepada tetangga atau kerabatnya sendiri. Tradisi upacara selamatan, ada nilai-nilai sosial kemasyarakatan yang mengarah pada kerukunan.

\section{Upaya Umat Beragama dalam Mengembangkan Sikap Toleransi}

Pada dasarnya, setiap ajaran agama yang dianut dan diyakini oleh setiap orang mengajarkan untuk saling menyayangi dan menghormati satu dengan yang lainnya, sehingga terbentuknya kerukunan sangat mudah terjalin secara alamiah. Karena masing-masing umat beragama dapat memahami dan mengamalkan ajaran agama yang mereka yakini, baik ajaran ritual perorangan, kelompok, bahkan dalam kehidupan sehari-hari.

Dari temuan di lapangan, tidak sedikit masyarakat yang dalam satu keluarga berbeda agama, tetapi tetap memiliki hubungan yang harmonis. Bagi mereka kelainan agama bukanlah menjadi api permusuhan, namun mereka menyadari betul perbedaan tersebut 
mesti di bina dan tidak saling mengganggu dalam kegiatan beribadah. Secara umum, hubungan sosial keagamaan disini yaitu tanggungjawab secara individu maupun kelompok, terutama para pemuka agama yang senantiasa menjalankan fungsinya sebagai kemaslahatan umat. Upaya rutin yang dilakukan oleh pemuka agama di Nggerukopa salah satunya yaitu melakukan doho sama (dialog) antara para toko agama.

\section{KESIMPULAN}

Berdasarkan uraian di atas, para peneliti menyimpulkan bahwa terwujudnya sikap toleransi antar umat beragama pada masyarakat Nggerukopa dapat dilihat dari kehidupan sehariharinya. Mereka mampu menjalani kehidupannya masing-masing tanpa harus memperdulikan perbedaan yang ada termasuk adanya perbedaan keyakinan terhadap agama yang dianut sehingga sikap toleransi dan kerukunan beragama dapat tercipta dengan baik. Ideliasme toleransi di hati mayarakat Nggerukopa tetap ada eksistensinya. Eksistensi masyarakat setempat selalu terpelihara dengan baik, tetap tertanam dan terjunjung tinggi melalui kegiatan-kegiatan atau acara-acara yang bersifat kebersamaan dimana melibatkan semua masyarakat seperti perayaan hari besar tiap masing-masing agama, tradisi upacara tradisonal bahkan pada hal yang simple yakni doho sama (dialog) anatr pemeluk kepercayaan agar bisa saling memahami dan saling mengerti terhadap apa yang sebenarnya terjadi di masyarakat.

\section{SARAN}

Kerukunan hidup berdampingan secara damai antara umat Kristen Dan Muslim Di Ngerukopa adalah sebagai pelajaran penting dan pedoman bagi seluruh warga negara Indonesia dalam berkehidupan antarumat berbeda agama.

\section{UCAPAN TERIMA KASIH}

Pandai bersyukur atas apa yang diberikan oleh Tuhan Yang Maha Esa merupakan bentuk sikap terpuji. Para peneliti mengetuk kalbu mengucapkan rasa syukur dan merendahkan hati berterima kasih kepada seluruh pihak-pihak yang mendukung jalannya penelitian ini sampai akhir.

\section{DAFTAR PUSTAKA}

Adeng Muchtar Ghazali (2016). Toleransi Beragama dan Kerukunan Dalam Perspektif Islam: Religious: Jurnal Agama dan Lintas Budaya. Vol. 1 No. 1, September 2016.

Akintan, Oluwatosin Adeoti (2014). Religious Tolerance and Peaceful Co-Existence: The Case of Female Religious Cults Relationship in Ijebuland, Ogun State Nigeria: Research on Humanities and Social Sciences, Vol.4, No.11, 2014.

Ali, Yusuf Faisal (2017). Upaya Tokoh Agama

Dalam Mengembangkan Sikap

Toleransi Antarumat Beragama: UCEJ, Vol. 2 No. 1, April 2017

Digdoyo, Eko (2018). Kajian Isu Toleransi Beragama, Budaya, Dan Tanggung Jawab Sosial Media: JPK: Jurnal Pancasila dan Kewarganegaraan, Vol. 3, No. 1, Januari 2018.

Mursyid, Salma (2016). Konsep Toleransi (Al-

Samahah) Antar Umat Beragama

Perspektif Islam: JURNAL AQLAM:

Journal of Islam and Plurality, Volume 2, Nomor 1, Desember 2016.

Musyarif (2018). Toleransi Islam Dan Kristen Di Kabupaten Soppeng Tahun 19502007: Zawiyah Jurnal Pemikiran Islam Vol. 4 No. 1 Juli 2018.

Nisvilyah, Lely (2013). Toleransi Antarumat Beragama Dalam Memperkokoh Persatuan Dan Kesatuan Bangsa (Studi Kasus Umat Islam Dan Kristen Dusun Segaran Kecamatan Dlanggu Kabupaten Mojokerto): Kajian Moral dan Kewargenegaraan Nomor 1 Volume 2 Tahun 2013.

Shittu, Abdulazeez Balogun (2013). Peaceful Co-Existence in a Multi-Religious Society: Islam and Christianity perspectives: International Journal of Islamic Thoughts, 2, 45-60, 2013

Syaifudin, Imam (2017). Interaksi Sosial Dalam Membangun Toleransi Antar Umat Beragama Di Dusun Dodol Desa Wonoagung Kecamatan Kasembon 
Terakreditasi Peringkat 5 (No. SK: 85/M/KPT/2020)

Kabupaten Malang: JPIPS: Jurnal Pendidikan Ilmu Pengetahuan Sosial, Vol. 4, No. 1, Desember 2017

Zamakhsari, Ahmad (2019). Kontestasi Umat Beragama (Studi Tentang Perdamaian dan Ketegangan Islam-Kristen di Kota Bekasi): Jurnal Balai Diklat Keagamaan Bandung Volume XIII Nomor 2 Tahun 2019. 